\title{
JOKOWI'S INITIATIVE FOR A COMPETITION TO CUT INDONESIAN REGULATIONS: RECOMMENDATIONS AND THE ROLE OF HIGHER EDUCATION INSTITUTIONS IN INDONESIA
}

\author{
Handa S. Abidin \\ Law Study Programme, Universitas Presiden \\ E-mail: handa.abidin@president.ac.id
}

\begin{abstract}
This research provides recommendations for the development of an initiative of the President of the Republic of Indonesia (Presiden Republik Indonesia), Joko Widodo (Jokowi), namely the implementation of a competition to cut Indonesian regulations, and relates these recommendations to the role of higher education institutions in Indonesia. The concept of "cutting" regulations should be developed into "managing." The competition should also widen the scope of what should be managed. Rather than being limited only to "regulations," the scope should include "laws and regulations as well as other relevant law and policy products." Furthermore, the competition could be a trigger for developing other related collaborations. The collaboration between relevant parties in the competition and other future collaborations can be classified as a form of mutual cooperation (gotong royong) which could contribute to the development of the quality of Indonesian law in general and specifically to the quality of laws and regulations and other relevant law and policy products in the context of Indonesia. This mutual cooperation could also bring direct benefits to the Central Government of the Republic of Indonesia (Pemerintah Pusat Republik Indonesia) and other relevant state-related institutions as well as to higher education institutions in Indonesia that are expected to be involved in the competition and in other future collaborations.
\end{abstract}

Keywords: competition to cut regulations, higher education institutions, Indonesian law

\section{A. INTRODUCTION}

In December 2017, the President of the Republic of Indonesia (Presiden Republik Indonesia) (hereafter: President), Joko Widodo (hereafter: Jokowi), introduced his initiative to create a competition to cut Indonesian regulations (Cabinet Secretariat 2017a). Jokowi even offered an award for the one who can cut the regulations (Cabinet Secretariat 2017a). There are many Indonesian regulations (Cabinet Secretariat 2017a). The number mentioned by Jokowi was 42,000 (Cabinet Secretariat 2017a; see also Cabinet Secretariat 2016a; for a further discussion on the number of regulations, see in general Abidin n.d. a). In principle, Jokowi expects that regulations should not be made if they create difficulties for society and lower the productivity of Indonesia (Cabinet Secretariat 2017a; see also Cabinet Secretariat 2015a; Cabinet Secretariat 2018; Cabinet Secretariat 2016b). More specifically, for example, 
he noted that extortion is very likely to be occurring using regulations (permits/licences/requirements) as tools (Cabinet Secretariat 2017a). This problem is contradictory to the noble purpose of regulations which is to implement public welfare in the context of Indonesia as a law state (Indrati S. used the Preamble of the 1945 Constitution of of the Republic of Indonesia (Undang-Undang Dasar Negara Republik Indonesia Tahun 1945) as the basis of her argument, see Indrati S. 2007, 1; Indonesian Constitution, Preamble and Article 1 Paragraph (3); Law 12/2011, General Explanation).

Previous research has noted that there is a perception that problems can only be solved by laws (undang-undang) (Anggono 2014, 7-8). It is also stated that there are still ministers and leaders of institutions who see producing laws as an achievement (Anggono 2014, 7-8). Furthermore, it has also been stated in previous research that there is a problem regarding the self-interest of institutions which are only concerned with their own sectors and have no concern for issues in other sectors in the context of the establishment of laws and regulations (Mahendra 2017, 168; see also NDPB 2015, I (the preface of the Minister of National Development Planning / the Head of National Development Planning Body, in Indonesian: Menteri Perencanaan Pembangunan Nasional / Kepala Badan Perencanaan Pembangunan Nasional); Jember Recommendations 2017, [1]; APHTN-HAN, Pusako, and Puskapsi, press release, 2). It must be pointed out to these institutions that the establishment of laws and regulations is not the only solution to their problems (NDPB 2015, III (the preface similar as above) and 44-45; in the context of laws, see Anggono 2014, 299).

As of 24 July 2018 the author has not been able to find a significant update or detailed information regarding the competition that is available to the public. As a result, there are a number of assumptions that could be made. One is that the competition initiative mentioned by Jokowi may not be a serious intention. Therefore, the initiative has not been followed up by the President / the Central Government of the Republic of Indonesia (Pemerintah Pusat Republik Indonesia) (hereafter: Central Government) (for an example regarding the definition of the Central Government (of the Republic of Indonesia), see Law Number 6 of 2017, Article 1 Number 11). It could also be that the statement regarding the competition was serious, but there are no resources available to follow it up.

Even if we assume the idea was not a serious statement, the initiative proposed by Jokowi is worthy of development. The competition is a part of a public participation that should be advanced further (for examples of other models of public participation, see: NDPB 2015, 52-53; for the legal basis in the context of public participations in the establishment of laws and regulations, see Law Number 12 of 2011, Article 96 and its explanation). The 
competition could contribute not only in terms of managing "regulations" but also in managing more than just "regulations."

In the context of the competition, Jokowi, quoted in the article mentioning the pertinent competition (available on the official website of the Secretary of the Cabinet of the Republic of Indonesia / Sekretariat Kabinet Republik Indonesia) said: "[n]anti mau saya buat lomba siapa yang bisa memangkas peraturan-peraturan saya beri hadiah" (Cabinet Secretariat 2017a). His statement can be translated and explained as: Jokowi wants to create a competition to cut regulations, and those who can cut regulations (peraturan) in the competition will receive an award (Cabinet Secretariat 2017a). Other related terms that Jokowi used in the article are "aturan" and "regulasi" which may be interpreted as regulations (Cabinet Secretariat 2017a). Jokowi also mentioned other terms such as "izin"/"perizinan" (permit/licence) and "persyaratan" (requirement) (Cabinet Secretariat 2017a). In the context of the article, the permits/licences and the requirements that are mentioned by Jokowi tend to be associated with and are in the scope of regulations - in other words, they are regulated under regulations (Cabinet Secretariat 2017a). Thus, in the context of this research, the permits/licences and the requirements will be stated as regulations (Cabinet Secretariat 2017a).

Nonetheless, it should be noted that there is a possibility that for example the permits/licences and the requirements (Cabinet Secretariat 2017a) are to be decided in the form of a law characteristic product other than a regulation, such as a decision (keputusan). In the context of a decision, it is also should be pointed out that there might be a pertinent decision already established before the Law of the Republic of Indonesia Number 12 of 2011 on the Establishment of Laws and Regulations (Undang-Undang Republik Indonesia Nomor 12 Tahun 2011 tentang Pembentukan Peraturan Perundang-undangan) (hereafter: Law Number 12 of 2011) which according to Article 100 of the Law Number 12 of 2011 should be interpreted as a regulation (see Law Number 12 of 2011, Article 100). There might also be a pertinent decision that was established after the Law Number 12 of 2011 and outside the context of Article 100 of the Law Number 12 of 2011 (see Law Number 12 of 2011, Article 100).

In principle, every single product that has the character of law or policy and which is being used to regulate or has an impact to the public should be the object of the competition. In the context of this research the term that will be used is: laws and regulations (for the legal basis in the context of the definition and the scope of laws and regulations, see Law 12 of 2011, Article 1 Number 2, Article 7 and its explanation, and Article 8 and its explanation) as 
well as other relevant law and policy products (for examples of law and policy products, see in general Abidin n.d. a). There are a number of reasons why laws and regulations as well as other relevant law and policy products need to be cut and managed, besides the reasons that Jokowi stated (for Jokowi's statements, see Cabinet Secretariat 2017a; see also Cabinet Secretariat 2015a; Cabinet Secretariat 2018; Cabinet Secretariat 2016b). According to the Ministry of National Development Planning of the Republic of Indonesia / the National Development Planning Body of the Republic of Indonesia (Kementerian Perencanaan Pembangunan Nasional Republik Indonesia / Badan Perencanaan Pembangunan Nasional Republik Indonesia) (hereafter: NDPB) in its report entitled Strategi Nasional Reformasi Regulasi: Mewujudkan Regulasi yang Sederhana dan Tertib (The national strategy for regulatory reform: Establishing simple and orderly regulations) (hereafter: NDPB National Strategy) regulations could have problems with other regulations (conflict and/or inconsistent) and/or could have problems internally inside the regulations (multiple interpretations and/or do not have operational content) (NDPB 2015, 38-39, 66-68, 88-89, and 93). Furthermore, according to the NDPB National Strategy, the possible steps after a regulation has been analysed are there could be no action (the regulation will be kept) or there could be an action (the regulation will be revised or repealed) (NDPB 2015, 40-41 and 6970).

It should be noted that the NDPB in its NDPB National Strategy interpreted "regulations" in a limited way-only in the context of laws and regulations (NDPB 2015, 3 and 92; but there is an inconsistency because the NDPB classified the president instructions (instruksi presiden) as "regulations" (laws and regulations), see 5). Nonetheless, the recommendations in the NDPB National Strategy could also be used in the context of other relevant law and policy products outside laws and regulations (see in general: NDPB 2015). In the context of this research the terms "regulations" and "laws and regulations" in relation to or referring to the NDPB National Strategy will be used interchangeably (see in general: NDPB 2015).

Jokowi has suggested an ambitious proposal to cut regulations, for instance, he has a stated intention to cut regulations in half and even until a quarter (Cabinet Secretariat 2016a). Jokowi also stated that he has ordered the direct cutting of 3,143 local regulations without the need for any review (Cabinet Secretariat 2016c). In the context of the competition, the concept should not simply "cut" laws and regulations as well as other relevant law and policy products. The legal system could be negatively impacted if laws and regulations as well as other relevant law and policy products are simply excised, for example, there would be a risk 
of a negative legal vacuum. The initiative must be developed into "managing" laws and regulations as well as other relevant law and policy products and making them harmonious (for the statements by Jokowi and the Minister of Law and Human Rights of the Republic of Indonesia regarding harmonisation but outside the context of the competition, see Cabinet Secretariat 2016d and MLHR 2017, 6-8). Therefore, reviews and research before cutting laws and regulations as well as other relevant law and policy products are seen as important. The positive and negative impacts if laws and regulations as well as other relevant law and policy products are removed must be explained in the proposals of the participants in the competition.

Nonetheless, it should be noted that in his other speeches, Jokowi recognised the importance of coordination and reviews when making laws and regulations-for example is in the context of a minister regulation - in order to avoid a regulation that could have a negative impact for the public (Cabinet Secretariat 2017b; Cabinet Secretariat 2017c; Cabinet Secretariat 2015b). Furthermore, Jokowi understands the need for harmonisation of regulations (Cabinet Secretariat 2016d). The spirit of harmonisation is also supported by the Minister of Law and Human Rights of the Republic of Indonesia (Menteri Hukum dan Hak Asasi Manusia Republik Indonesia) (MLHR 2017, 6-8). The minister also supported the concept of managing regulations (MLHR 2017, 1 (see the title) and 5). Under the Law Number 12 of 2011 there are also processes of review and alignment in the establishment of laws (Law Number 12 of 2011, Article 19 Paragraph (3) and its explanation).

Moreover, the NDPB National Strategy stated that there is a need for a regulatory reform to improve the quality of regulations (NDPB 2015, 13-14 and 92), and one of the short-term goals is to control the quantity of regulations by simplifying them (NDPB 2015, 57, see also 14-15). The NDPB National Strategy also pointed out the need for the quality and quantity of regulations to be managed in order to create regulations that are simple and in order (NDPB 2015, 8; for an explanation of the main functions of regulations, see 4). It should also be pointed out that the Jember Recommendations concerning the Arrangement of Regulations in Indonesia, which resulted from the $4^{\text {th }}$ National Conference on Constitutional Law in Jember, supported the concept of reducing and harmonising regulations in the context of the arrangement of regulations (Jember Recommendations 2017).

This research aims to develop the competition idea mentioned by Jokowi. The research will give recommendations regarding the concept of the competition as well as discussing a number of technical implementations. Furthermore, this research will consider 
the benefits and the challenges of the competition. It is expected that the proposed research will provide contributions if the competition is implemented.

It should be noted that there are many parties that could potentially participate in the competition. Nonetheless, this research will only focus on the role of higher education institutions in Indonesia in the competition as well as the Central Government and other relevant state-related institutions that will be discussed in the next chapter. It should also be noted that the research does not claim to have a complete blueprint for the competition. Thus, further development of the recommendations in this research should be made. Moreover, in the context of the competition, the research has no intention to undertake a comparative study with other practices in other states (if any). This research is focused on the Indonesian context and should be interpreted as such.

\section{B. RECOMMENDATIONS}

There are many tools that could be used to examine laws and regulations as well as other relevant law and policy products. Pancasila and the 1945 Constitution of the Republic of Indonesia (Undang-Undang Dasar Negara Republik Indonesia Tahun 1945) must be the basis of the examination of laws and regulations as well as other relevant law and policy products (Law Number 12 of 2011, Article 2 and its explanation and Article 3 Paragraph (1) and its explanation; see also Cabinet Secretariat 2017d; see in general Abidin n.d. b). International indexes could be used as tools to examine laws and regulations as well as other relevant law and policy products (see in general Abidin n.d. b). Another tool that could be used is the tool of cost and benefit analysis (hereafter: CBA) which has been developed by other states (in the context of Canada, see Treasury Board of Canada Secretariat 2007 and Treasury Board of Canada Secretariat 2009; in the context of the United States of America, see Exec. Order No. 12, 866, 58 Fed. Reg. 190 (Oct. 4, 1993) and Exec. Order No. 13, 563, 76 Fed. Reg. 14 (Jan. 21, 2011)). It should be noted that the NDPB has also a CBA tool that could be used to examine in the context of the establishment of laws and regulations (NDPB 2015, 78-86) as well as other relevant law and policy products. Although the CBA tool explained by the NDPB tends to be employed in the context of future regulations (NDPB 2015, 41-44 and 78-86), it would be also suitable to use it to examine existing laws and regulations as well as other relevant law and policy products.

The NDPB also has developed another tool called the Instrument for Regulations Simplification (Instrumen Simplifikasi Regulasi / ISR) (NDPB 2015, 37-41, 61-77, and 88). The Instrument for Regulations Simplification is a tool to assess problematic regulations 
(NDPB 2015, 88 and in general 37-41 and 61-77) which will also be relevant in the context of other relevant law and policy products. These tools that have already been developed by the NDPB could be used by participants in the competition (NDPB 2015, 61-86). Other useful analytical tools such as the precautionary principle (for a further discussion on the precautionary principle but not specifically in the context of Indonesian law, see Latifah 2016, 275-297) could also be used to examine existing and future laws and regulations as well as other relevant law and policy products.

Indonesia has 3,276 higher education institutions under the Ministry of Research, Technology, and Higher Education of the Republic of Indonesia (Kementerian Riset, Teknologi, dan Pendidikan Tinggi Republik Indonesia) (hereafter: MRTHE) based on the MRTHE statistical report published in 2017 (MRTHE 2017, 15). Higher education institutions are available in all provinces in Indonesia (MRTHE 2017, 16). The types of higher education institution according to a report by the MRTHE are also varied (for the types of higher education institution and their specific number, see MRTHE 2017, 27). It should be noted that, in practice, the MRTHE is not the only ministry/institution that manages higher education institutions in Indonesia (MRTHE 2016, 36). There are also other ministries/institutions that do so (MRTHE 2016, 36). Thus, the number of higher education institutions in Indonesia, if including those which are not managed by the MRTHE, will be larger than the number above (MRTHE 2016, 36). The pertinent statistical report by the MRTHE also stated that there are 20,516 study programmes in higher education institutions under the MRTHE which consisting of programmes on various of subjects (for the subjects and the specific number of the programmes, see MRTHE 2017, [31] and 15). In terms of lectures and students, there are 247,269 lecturers and 6,924,511 registered students under the MRTHE based on the pertinent statistical report by the MRTHE (MRTHE 2017, 15). The numbers in this paragraph describe the possibility of the involvement of a significant number of participants in the competition in the context of higher education institutions.

There at least four parties that will be involved in the competition. The first is the Central Government which is expected to officially manage the competition. The second is the participants in the competition which in the context of this research will be higher education institutions in Indonesia. The third is parties that will become the partners of the Central Government which will be explained below. The fourth is parties from the judicial branch which will also be discussed below.

The Central Government should establish the systems for the competition. For example, the Central Government should establish a system for online submission. As 
mentioned by Jokowi the winner of the competition will receive an award (Cabinet Secretariat 2017a). Thus, the Central Government should provide the awards for the winner of the competition. In the context of tourism-but not specifically in the context of a competition - the forms of awards for the recipient could be divided into two classifications which are: certificate or money (specific awards) and another form which could be widely interpreted namely other beneficial awards (President Regulation Number 50 of 2016, Article 4 and see also Article 5). Furthermore, it is important to note that the competition will be more effective if all laws and regulations as well as other relevant law and policy products are made available to the public through an online Indonesian law database (for a discussion regarding an online Indonesian law database, see in general Abidin n.d. a).

The technical implementation of the competition could be started via courses in higher education institutions in Indonesia. For example, a lecturer in charge of a Capital Market Law course in a law study programme could include the competition in the syllabus and give assignments to students to find relevant laws and regulations as well as other relevant law and policy products which should be cut and managed in the context of Capital Market Law. The lecturers could also involve in the competition but in a specific category for lecturers only. The competition could be held every semester in order to integrate it into the curriculums of the study programmes.

The integration of the competition in the curriculum should be done voluntarily by higher education institutions. Any study programmes may be involved. It should be underlined that the competition is not limited to law study programmes alone. All study programmes could give proposals to cut and manage laws and regulations as well as other relevant law and policy products in their context of knowledge.

After a participant submits a proposal, there must be a significant follow-up from the Central Government. Otherwise, the competition will not be optimally designed to effectively manage laws and regulations as well as other relevant law and policy products. Proposals that are selected by the board of judges (for the context of tourism but not specifically in the context of a competition (the assessor team), see President Regulation Number 50 of 2016, Article 12) of the competition as being worthy to be followed up should receive awards. The form of the awards will depend on the significance of the proposals for Indonesia (for the context of tourism but again not specifically in the context of a competition, see President Regulation Number 50 of 2016, Articles 4-9 and see also Article 13).

Reviews may be carried out by executive, legislative, and judicial institutions (Asshiddiqie (2010) 2014, 74; Taib 2017, 264; Anggono 2014, 243-244; for the definition of 
an executive review, a legislative review, and a judicial review by the NDPB (it should be noted that the NDPB has a limited scope on interpreting the legislative review that only focused in the context of laws), see NDPB 2015, 88-89 and see also 61-62). Because the competition will be managed by the Central Government, an executive review by the Central Government is the most feasible course of action compared to legislative and judicial reviews. An executive review in the context of the Central Government may be done only if the Central Government has the authority to amend or repeal laws and regulations as well as other relevant law and policy products. For example, if a proposal suggests that a president regulation should be amended, and the argument of the proposal is valid, the Central Government should be able to directly revise the president regulation (for the legal basis on the drafting of a president regulation, see Law Number 12 of 2011, Article 55). Nonetheless, an executive review by the Central Government would be limited in that it would not be able to repeal provincial as well as city and regency regulations (for the legal basis of the Supreme Court of the Republic of Indonesia (Mahkamah Agung Republik Indonesia) to review laws and regulations that are under laws, see Indonesian Constitution, Article 24A Paragraph (1); Law Number 12 of 2011, Article 9 Paragraph (2); Law Number 48 of 2009, Article 20 Paragraph (2) Letter b and its explanation and Paragraph (3); and Law Number 3 of 2009, Article I Number 11 Article $31 \mathrm{~A}$ and its explanation; for the Constitutional Court of the Republic of Indonesia (Mahkamah Konstitusi Republik Indonesia) decisions on the pertinent matter, see Constitutional Court, Decision Number 137/PUU-XIII/2015 and Constitutional Court, Decision Number 56/PUU-XIV/2016; for a further discussion regarding the Supreme Court, see Asshiddiqie (2010) 2014, 76-77; Taib 2017, 267 and 281-289; and Astawa and Na'a (2008) 2012, 124-125; for the number of judicial review cases regarding local regulations from 2016 until 2017, see Supreme Court 2018, 38 and Supreme Court 2017, 7778) (hereafter: note 1). Such an executive review would also not cover, for example, laws (undang-undang) (for the legal basis of the Constitutional Court to review laws, see Indonesian Constitution, Article 24C Paragraph (1); Law 12/2011, Article 9 Paragraph (1); Law Number 24 of 2003, Article 10 Paragraph (1) (and its explanation) Letter a; Law Number 8 of 2011, Article I Number 8 (explanation of Article 10 Paragraph (1)); Law Number 48 of 2009, Article 29 Paragraph (1) Letter a; for a further discussion regarding the Constitutional Court, see Taib 2017, 271-281) (hereafter: note 2). The Central Government is not the only party that is involved in the establishment (including the amendment) of laws (Indonesian Constitution, Article 5, Article 20 Paragraph (1), and Article 22D Paragraphs (1)(2); Law Number 12 of 2011, Articles 43-51 and their explanations, and Articles 65-74 and 
their explanations). There is also the People's Representative Council of the Republic of Indonesia (Dewan Perwakilan Rakyat Republik Indonesia) (hereafter: PRC); and the Local's Representative Council of the Republic of Indonesia (Dewan Perwakilan Daerah Republik Indonesia) which could also be involved in certain matters (Indonesian Constitution, Article 5, Article 20 Paragraph (1), and Article 22D Paragraphs (1)-(2); Law Number 12 of 2011, Articles 43-51 and their explanations, and Articles 65-74 and their explanations).

The Central Government is also not the only party involved in the establishment (including the amendment) of provincial as well as city and regency regulations (Indonesian Constitution, Article 18 Paragraph (2); Law Number 12 of 2011, Articles 56-63 and their explanations, and Articles 75-80 and their explanations). Governors and provincial people's representative councils as well as regents and mayors also regency and city people's representative councils have more significant roles in the establishment (including the amendment) of provincial as well as city and regency regulations respectively (in their own context) (Indonesian Constitution, Article 18 Paragraph (2); Law Number 12 of 2011, Articles 56-63 and their explanations, and Articles 75-80 and their explanations). Thus, a partnership between the Central Government, governors, and provincial people's representative councils as well as between regents and mayors also regency and city people's representative councils should be established in the context of the competition.

A review of provincial as well as city and regency regulations could also be carried out via a judicial review procedure by the Supreme Court of the Republic of Indonesia (Mahkamah Agung Republik Indonesia) (hereafter: Supreme Court) (see note 1), and for laws via a judicial review procedure of the Constitutional Court of the Republic of Indonesia (Mahkamah Konstitusi Republik Indonesia) (hereafter: Constitutional Court) (see note 2). Laws only can be reviewed by the Constitutional Court (see note 2). Laws and regulations below laws and other relevant law and policy products below laws can be reviewed by the Supreme Court (see note 1).

It should be noted that there is no regulation regarding a periodic review process in the context of legislative and executive reviews in Indonesia (Anggono 2014, 243-245). However, the NDPB has recommended that periodic legislative and executive reviews should be implemented (NDPB 2015, 62). For the context of a legislative review, there must be a partnership between the Central Government and the legislative branch in the competition, in order for proposals to be reviewed by the legislative branch. Furthermore, the Central Government should also establish a partnership with independent state institutions (for a further discussion regarding independent state institutions, see Mochtar 2017, 206-208 and 
57-64; see also MSAUBR n.d.). and other state institutions outside the Central Government (for examples of other state institutions outside the government, see in general Indonesian Constitution) in the context of the competition.

For the context of a judicial review in the context of the Constitutional Court (limited to laws) and the Supreme Court, the nullification of laws and regulations and other relevant law and policy products may only be done by the parties stipulated in relevant laws and regulations (in the context of the Supreme Court, see Law Number 3 of 2009, Article I Number 11 (Article 31A) and its explanation; in the context of the Constitutional Court, see Law Number 24 of 2003, Article 51 and its explanation). For the Supreme Court, the petitioners could be a natural person (an Indonesian citizen) or a juridical person (a public or private legal entity) (Law Number 3 of 2009, Article I Number 11 (Article 31A) and its explanation). Furthermore, existing indigenous peoples (masyarakat hukum adat) could also be a petitioner in the context of the Supreme Court above (Law Number 3 of 2009, Article I Number 11 (Article 31A) and its explanation). For the Constitutional Court, the petitioners are similar to the Supreme Court, but with one more type of petitioner which is a state institution (Law Number 24 of 2003, Article 51 and its explanation). The process of a judicial review must be independent without intervention from any parties (see Indonesian Constitution, Article 24 Paragraph (1); Law Number 48 of 2009, Article 3 and its explanation) including from the Central Government.

Nonetheless, it should be noted that other relevant law and policy products (outside laws and regulations) of the Constitutional Court and the Supreme Court other than court decisions - inter alia: circular letter-may also be reviewed administratively by the Constitutional Court and the Supreme Court as an alternative to a judicial review by the Supreme Court (for the context of a judicial review by the Supreme Court, see note 1). In order to connect this to the competition, a partnership regarding the competition between the Central Government and the Constitutional Court as well as the Supreme Court should be established.

For Indonesia as a state including the Central Government and other relevant legislative and judicial parties, the competition will help them to evaluate existing laws and regulations as well as other relevant law and policy products. For higher education institutions the competition will be an important opportunity to strengthen collaboration with Indonesia as a state in contributing to developing the Indonesian legal system (for the components of Indonesian law as a national law, see Mahendra 2017, 167-168 (citing the research of the National Law Development Body / Badan Pembinaan Hukum Nasional in 
1995/1996)) (hereafter: note 3). Students can learn the law and policy related to their subject of study. While lecturers can improve their research on the law and policy related to their subject of study as well.

The competition is also expected to be a trigger for further collaborations. Previous research suggested that the PRC should be a laboratory for higher education institutions (Siahaan 2012, 532). For instance, lecturers and students could use the PRC as their research object (Siahaan 2012, 532) and develop other relevant collaborations (for a further discussion on collaborations between universities and companies, see Lutchen 2018). This suggestion is also relevant to the Central Government and local government (for an example regarding the definition of a local government, see Law Number 6 of 2017, Article 1 Number 12) institutions and other relevant state related institutions (for a further discussion regarding independent state institutions, see Mochtar 2017, 206-208 and 57-64; see also MSAUBR n.d.; for examples of other state institutions outside the government, see in general Indonesian Constitution). The pertinent laboratories are expected not only to provide materials for research but also to provide necessary training for to lecturers and students. Lecturers and students are expected to gain practical experience in the pertinent laboratories (Siahaan 2012, 532). In the future, collaboration could also take place in the context of previews or before laws and regulations as well as law and policy products are established (for a further discussion in the context of the preview, see Asshiddiqie (2010) 2014, 74-75 and 77; Yuliandri (2009) 2010, 252). A preview could reduce time and cost by minimising the risk that laws and regulations as well as other relevant law and policy products will be challenged in the Constitutional Court or the Supreme Court (for a further discussion of laws that were challenged in the Constitutional Court as well as local regulations that have problems, see Mahendra 2017, 158-161, and for the cost of the National Legislation Programme 2011-2016 (Program Legislasi Nasional 2011-2016), see 149; for the number of judicial reviews on laws from 2003 until 2007, see Constitutional Court 2018, 14-15).

In general, the competition could contribute to achieve one of the purposes of higher education which is to benefit Indonesia by supporting it to progress as a nation through the research in the competition (Law Number 12 of 2012, Article 5 Letter c, see also Letters b and $\mathrm{d}$ and its explanation). The above collaboration will be expected to increase the competitiveness of students after they have graduated (for a further discussion of collaborations between companies and educators (also in the context of students), see Runnion and Gibson 2018). Students will not only understand their subject of study, but also 
the law and policy surrounding their subject. For law students, it will deepen their understanding of law and policy.

The competition is expected to bring benefits to all the parties involved. The collaboration in the context of the competition or beyond the competition can be classified as a form of mutual cooperation (gotong royong) between the parties mentioned above, with the aim of developing the quality of Indonesian law in general and the quality of laws and regulations as well as other relevant law and policy products from various sectors in specific. Furthermore, it is expected that this level of collaboration could develop and increase the quality of the Indonesian legal system (see note 3). which could increase the prosperity of Indonesia.

There are still limitations in the current processes and technical aspect of the establishment of laws and regulations as well as other relevant law and policy products. For instance, there is a limitation on the number of expert staff in the PRC (Siahaan 2012, 466469). The quality and quantity of legal drafters is also an important problem that should be addressed (Mahendra 2017, 161-165; NDPB 2015, 50-51; for a criticism in the context of local people's representative council (dewan perwakilan rakyat daerah), see Lubis 2009, 6263). Furthermore, it should be noted that previous research has noted that public participations in the establishment of laws is still weak (Anggono 2014, 242-243; for a further discussion on public participation in the context of the Law of the Republic of Indonesia Number 10 of 2004 on the Establishment of Laws and Regulations (UndangUndang Republik Indonesia Nomor 10 Tahun 2004 tentang Pembentukan Peraturan Perundang-undangan) which has already been repealed and expired but still relevant to read, see Saifudin 2009, [337]-344; see also in general Law Number 10 of 2004).

The competition is expected to not only contribute to encouraging public participations in the establishment of laws and regulations as stipulated under Article 96 and its explanation of the Law 12/2011 (Law Number 12 of 2011, Article 96 and its explanation) but also to the establishment of other relevant law and policy products. Moreover, Jokowi also has an expectation that the public should be consulted by ministries regarding ministry regulations and policies that they wish to establish (Cabinet Secretary 2017e; Cabinet Secretariat 2017b).

One of the challenges of the competition is its management. For instance, not all the proposals from the participants will be of a high standard and capable of making a contribution to improving the quality of laws and regulations as well as law and policy products. Therefore, the process of selection-including how to harmonise proposals that 
meet the standards needed by the legal system-will require the Central Government to manage the competition. However, it should be noted that the Central Government could request the assistance of relevant third parties in this regard. In the context of the students' segment, lecturers could play an important role to teach the students to make proposals that meet the required standards.

Another challenge for the implementation of the competition will be the political will of the Central Government itself, in particular the political will of Jokowi to commit to and implement the competition as well as other further collaborations. Nonetheless, the Central Government cannot effectively implement the competition without the collaboration of the other parties mentioned in this research. Thus, these parties would be expected to support the competition as well as further collaborations.

\section{CONCLUSION}

Jokowi's initiative for a competition to cut regulations is a breakthrough idea that is worthy of being developed. The implementation of the competition is feasible, but it depends on the political will of the Central Government, in particular the political will of Jokowi, as well as the willingness of other relevant parties mentioned in this research to collaborate in the competition. It is expected that the recommendations in this research-inter alia, the concept of the competition (managing not cutting) and the scope of the competition (laws and regulations as well as other relevant law and policy products, not only regulations) - will be considered by the Central Government if the competition goes on to be implemented. It is also expected that the competition will trigger further collaborations that will bring benefits to all parties involved. 


\section{REFERENCE LIST}

\section{Laws and Regulations (Indonesian):}

Peraturan Presiden Republik Indonesia Nomor 50 Tahun 2016 tentang Pemberian Penghargaan Kepariwisataan [President of the Republic of Indonesia Regulation Number 50 Year 2016 concerning Giving Tourism Awards] (President Regulation Number 5 of 2016) (LNRI Year 2016 Number 107) (stipulated 7 June 2016, promulgated 10 June 2016).

Undang-Undang Dasar Negara Republik Indonesia Tahun 1945 [The 1945 Constitution of the Republic of Indonesia]

Undang-Undang Republik Indonesia Nomor 10 Tahun 2004 tentang Pembentukan Peraturan Perundang-undangan [Law of the Republic of Indonesia Number 10 of 2004 on the Establishment of Laws and Regulations] (Law 10/2004) (LNRI Year 2004 Number 53, TLNRI Number 4389) (authorised 22 June 2004, promulgated 22 June 2004).

Undang-Undang Republik Indonesia Nomor 12 Tahun 2011 tentang Pembentukan Peraturan Perundang-undangan [Law of the Republic of Indonesia Number 12 of 2011 on the Establishment of Laws and Regulations] (Law 12/2011) (LNRI Year 2011 Number 82, TLNRI Number 5234) (authorised 12 August 2011, promulgated 12 August 2011).

Undang-Undang Republik Indonesia Nomor 12 Tahun 2012 tentang Pendidikan Tinggi [Law of the Republic of Indonesia Number 12 of 2012 on Higher Education] (Law 12/2012) (LNRI Year 2012 Number 158, TLNRI Number 5336) (authorised 10 August 2012, promulgated 10 August 2012).

Undang-Undang Republik Indonesia Nomor 24 Tahun 2003 tentang Mahkamah Konstitusi [Law of the Republic of Indonesia Number 24 of 2003 on the Constitutional Court] (Law 24/2003) (LNRI Year 2003 Number 98, TLNRI Number 4316) (authorised 13 August 2003, promulgated 13 August 2013).

Undang-Undang Republik Indonesia Nomor 3 Tahun 2009 tentang Perubahan Kedua atas Undang-Undang Nomor 14 Tahun 1985 tentang Mahkamah Agung [Law of the Republic of Indonesia Number 3 of 2009 on the Second Amendment of the Law Number 14 of 1985 on the Supreme Court] (Law 3/2009) (LNRI Year 2009 Number 3, TLNRI Number 4958) (authorised 12 January 2009, promulgated 12 January 2009).

Undang-Undang Republik Indonesia Nomor 48 Tahun 2009 tentang Kekuasaan Kehakiman [Law of the Republic of Indonesia Number 48 of 2009 on Judicial Powers] (Law 48/2009) (LNRI Year 2009 Number 157, TLNRI Number 5076) (authorised 29 October 2009, promulgated 29 October 2009).

Undang-Undang Republik Indonesia Nomor 6 Tahun 2017 tentang Arsitek [Law of the Republic of Indonesia Number 6 of 2017 on Architects] (Law 6/2017) (LNRI Year 2017 Number 179, TLNRI Number 6108) (authorised 8 August 2017, promulgated 8 August 2017). 
Undang-Undang Republik Indonesia Nomor 8 Tahun 2011 tentang Perubahan atas UndangUndang Nomor 24 Tahun 2003 tentang Mahkamah Konstitusi [Law of the Republic of Indonesia Number 8 of 2011 on the Amendment of the Law Number 24 of 2003 on the Constitutional Court] (Law 8/2011) (LNRI Year 2011 Number 70, TLNRI Number 5226) (authorised 20 July 2011, promulgated 20 July 2011).

\section{Decisions:}

Mahkamah Konstitusi Republik Indonesia, Putusan Nomor 137/PUU-XIII/2015, Pengujian Undang-Undang Nomor 23 Tahun 2014 tentang Pemerintahan Daerah terhadap UndangUndang Dasar Negara Republik Indonesia Tahun 1945 [Constitutional Court of the Republic of Indonesia, Decision Number 137/PUU-XIII/2015, Review on the Law Number 23 Year 2014 concerning Local Governments on the Constitution of the State of the Republic of Indonesia Year 1945] (Constitutional Court, Decision Number 137/PUUXIII/2015), Pemohon [Petitioners]: (1) Asosiasi Pemerintah Kabupaten Seluruh Indonesia (APKASI), (2) Pemerintah Daerah Kabupaten Batubara, Provinsi Sumatera Utara, (3) Pemerintah Daerah Kabupaten Aceh Tengah, Provinsi Aceh, (4) Pemerintah Daerah Kabupaten Muara Enim, Provinsi Sumatera Selatan, (5) Pemerintah Daerah Kabupaten Belitung, Provinsi Bangka Belitung, (6) Pemerintah Daerah Kabupaten Merangin, Provinsi Jambi, (7) Pemerintah Daerah Kabupaten Tanjung Jabung Barat, Provinsi Jambi, (8) Pemerintah Daerah Kabupaten Lampung Timur, Provinsi Lampung, (9) Pemerintah Daerah Kabupaten Tanggamus, Provinsi Lampung, (10) Pemerintah Daerah Kabupaten Lebak, Provinsi Banten, (11) Pemerintah Daerah Kabupaten Bandung Barat, Provinsi Jawa Barat, (12) Pemerintah Daerah Kabupaten Majalengka, Provinsi Jawa Barat, (13) Pemerintah Daerah Kota Sukabumi, Provinsi Jawa Barat, (14) Pemerintah Daerah Kabupaten Banjarnegara, Provinsi Jawa Tengah, (15) Pemerintah Daerah Kabupaten Pati, Provinsi Jawa Tengah, (16) Pemerintah Daerah Kabupaten Kulon Progo, Provinsi Daerah Istimewa Yogyakarta, (17) Pemerintah Daerah Kabupaten Madiun, Provinsi Jawa Timur, (18) Pemerintah Daerah Kabupaten Trenggalek, Provinsi Jawa Timur, (19) Pemerintah Daerah Kabupaten Bangli, Provinsi Bali, (20) Pemerintah Daerah Kabupaten Kapuas, Provinsi Kalimantan Tengah, (21) Pemerintah Daerah Kabupaten Bulungan, Provinsi Kalimantan Utara, (22) Pemerintah Daerah Kabupaten Gorontalo Utara, Provinsi Gorontalo, (23) Pemerintah Daerah Kabupaten Sumbawa, Provinsi Nusa Tenggara Barat, (24) Pemerintah Daerah Kabupaten Serdang Bedagai, Provinsi Sumatera Utara, (25) Pemerintah Daerah Kabupaten Lamandau, Provinsi Kalimantan Tengah, (26) Pemerintah Daerah Kabupaten Cilacap, Provinsi Jawa Tengah, (27) Pemerintah Daerah Kabupaten Tangerang, Provinsi Banten, (28) Pemerintah Daerah Kabupaten Nias, Provinsi Sumatera Utara, (29) Pemerintah Daerah Kabupaten Minahasa Tenggara, Provinsi Sulawesi Utara, (30) Pemerintah Daerah Kabupaten Kolaka, Provinsi Sulawesi Tenggara, (31) Pemerintah Daerah Kabupaten Sarolangun, Provinsi Jambi, (32) Pemerintah Daerah Kabupaten Sigi, Provinsi Sulawesi Tengah, (33) Pemerintah Daerah Kabupaten Konawe, Sulawesi Tenggara, (34) Pemerintah Daerah Kabupaten Sidoarjo, Provinsi Jawa Timur, (35) Pemerintah Daerah Kabupaten Dairi, Provinsi Sumatera Utara, (36) Pemerintah Daerah Kabupaten Lampung Selatan, Provinsi Lampung, (37) Pemerintah Daerah Kabupaten Kupang, Provinsi Nusa Tenggara Timur, (38) Pemerintah Daerah Kabupaten Sumba Tengah, Provinsi Nusa Tenggara Timur, (39) Pemerintah Daerah Kabupaten Lombok Timur, Provinsi Nusa Tenggara Barat, (40) Pemerintah Daerah Kabupaten Balangan, Provinsi Kalimantan Selatan, (41) Pemerintah Daerah Kabupaten Tapanuli Selatan, Provinsi Sumatera Utara, (42) Pemerintah Daerah Kabupaten Magetan, Provinsi Jawa Timur, (43) Pemerintah Daerah Kabupaten Tabanan, Provinsi Bali, (44) Pemerintah 
Daerah Kabupaten Batang, Provinsi Jawa Tengah, (45) Pemerintah Daerah Kabupaten Sumedang, Provinsi Jawa Barat, (46) Pemerintah Daerah Kabupaten Soppeng, Provinsi Sulawesi Selatan, and (47) Ibnu Jandi (the verdict was spoken for the public on 5 April 2017).

Mahkamah Konstitusi Republik Indonesia, Putusan Nomor 56/PUU-XIV/2016, Pengujian Undang-Undang Nomor 23 Tahun 2014 tentang Pemerintahan Daerah terhadap UndangUndang Dasar Negara Republik Indonesia Tahun 1945 [Constitutional Court of the Republic of Indonesia, Decision Number 56/PUU-XIV/2016, Review on the Law Number 23 Year 2014 concerning Local Governments on the Constitution of the State of the Republic of Indonesia Year 1945] (Constitutional Court, Decision Number 56/PUUXIV/2016), Pemohon [Petitioners]: (1) Abda Khair Mufti, (2) Muhammad Hafidz, (3) Amal Subkhan, (4) Solihin, and (5) Totok Ristiyono (the verdict was spoken for the public on 14 June 2017).

\section{Books:}

Anggono, Bayu Dwi. 2014. Perkembangan Pembentukan Undang-Undang di Indonesia [The development of the establishment of laws in Indonesia]. Jakarta: Konstitusi Press.

Asshiddiqie, Jimly. (2010) 2014. Perihal Undang-Undang [Regarding laws]. Reprint, Jakarta: PT Rajagrafindo Persada.

Astawa, I Gde Pantja, and Supri Na'a. (2008) 2012. Dinamika Hukum dan Ilmu Perundangundangan di Indonesia [The dynamic of law and the science of laws in Indonesia]. Reprint, Bandung: PT Alumni.

Indrati S., Maria Farida. 2007. Ilmu Perundang-undangan (1) (Jenis, Fungsi, dan Materi Muatan) (Dikembangkan dari Perkuliahan A. Hamid S. Attamimi) [The science of laws (1) (Types, functions, and content materials) (Developed from A. Hamid S. Attamimi's lectures)]. Yogyakarta: Kanisius.

Lubis, M. Solly. 2009. Ilmu Pengetahuan Perundang-undangan [The science of laws]. Bandung: CV Mandar Maju.

Mahendra, A. A. Oka. 2017. Pedoman Praktis Legal Drafting: Panduan Praktis Merancang Peraturan Perundang-undangan secara Jelas dan Efektif [Practical guidelines for legal drafting: Practical steps to clearly and effectively draft laws and regulations]. Malang: Setara Press.

Mahkamah Agung Republik Indonesia (Tim Pokja Laporan Tahunan MARI) (Supreme Court). 2018. Laporan Tahunan 2017 Mahkamah Agung Republik Indonesia [The 2017 annual report of the Supreme Court of the Republic of Indonesia]. Jakarta: Mahkamah Agung RI.

Mochtar, Zainal Arifin. 2017. Lembaga Negara Independen: Dinamika Perkembangan dan Urgensi Penataannya Kembali Pasca-Amandemen Konstitusi [The independent state institutions: The dynamic of the development and the urgency of its rearrangement after the post-amendment of the constitution]. Depok: Rajawali Pers. 
Pokja Laporan Tahunan MARI (Supreme Court). 2017. Laporan Tahunan 2016 Mahkamah Agung Republik Indonesia [The 2016 annual report of the Supreme Court of the Republic of Indonesia]. Jakarta: Mahkamah Agung RI.

Saifudin. 2009. Partisipasi Publik dalam Pembentukan Peraturan Perundang-undangan [The public participations in the establishment of laws and regulations]. Yogyakarta: FH UII Press.

Siahaan, Pataniari. 2012. Politik Hukum Pembentukan Undang-Undang Pasca Amandemen UUD 1945 [The politics and the law on the establishment of laws after the amendment of UUD 1945]. Jakarta: Konpress.

Taib, Mukhlis. 2017. Dinamika Perundang-undangan di Indonesia (The dynamic of laws in Indonesia]. Bandung: Refika Aditama.

Treasury Board of Canada Secretariat. 2007. Canadian Cost-Benefit Analysis Guide Regulatory Proposals (Her Majesty the Queen in Right of Canada, Represented by the President of the Treasury Board).

Treasury Board of Canada Secretariat. 2009. Business Case Guide (Her Majesty the Queen in Right of Canada, Represented by the President of the Treasury Board).

Yuliandri. (2009) 2010. Asas-asas Pembentukan Peraturan Perundang-undangan yang Baik: Gagasan Pembentukan Undang-Undang Berkelanjutan [The principles of the establishment of good laws and regulations: Ideas for the establishment of sustainable laws]. Reprint, Jakarta: PT Rajagrafindo.

\section{Other Sources:}

Abidin, Handa S. n.d. a. "The Proposed Forms of Content for an Online Indonesian Law Database." (The draft has been submitted to a law journal).

Abidin, Handa S. n.d. b. "Pedoman Peraturan Perundang-undangan di Indonesia: Peran Indeks Internasional" [The guidelines for laws and regulations in Indonesia: The role of international indexes]. (The draft has been submitted to a law journal).

Asosiasi Pengajar Hukum Tata Negara dan Hukum Administrasi Negara (APHTN-HAN), Pusat Studi Konstitusi (Pusako) Universitas Andalas, dan Pusat Pengkajian Pancasila dan Konstitusi (Puskapsi) Universitas Jember (APHTN-HAN, Pusako, and Puskapsi). 2017. "Siaran Pers Konferensi Nasional Hukum Tata Negara (KNHTN) ke-4, Tema: Penataan Regulasi di Indonesia, 10-12 November 2017" [The press release of the $4^{\text {th }}$ National Conference on Constitutional Law, theme: the regulations arrangement in Indonesia. Jember, 10-12 November 2017].

Exec. Order No. 12, 866, 58 Fed. Reg. 190 (Oct. 4, 1993).

Exec. Order No. 13, 563, 76 Fed. Reg. 14 (Jan. 21, 2011). 
Kementerian Pendayagunaan Aparatur Negara dan Reformasi Birokrasi Republik Indonesia (Minister of State Apparatus Utilisation and Bureaucracy Reform) (MSAUBR). n.d. "Lembaga Non Struktural" [Non-structural institutions]. Accessed 24 July 2018. https://www.menpan.go.i d/site/kelembagaan/lembaga-non-struktural-2.

Kementerian Perencanaan Pembangunan Nasional / Badan Perencanaan Pembangunan Nasional. 2015. Strategi Nasional Reformasi Regulasi: Mewujudkan Regulasi yang Sederhana dan Tertib [The national strategy for regulatory reform: Establishing simple and orderly regulations] (NDPB). Kementerian Perencanaan Pembangunan Nasional / Badan Perencanaan Pembangunan Nasional.

Kementerian Riset, Teknologi, dan Pendidikan Tinggi Republik Indonesia (Ministry of Research, Technology, and Higher Education) (MRTHE). 2016. Puspawarna Pendidikan Tinggi Indonesia [The puspawarna (the colourfulness) of higher education in Indonesia]. Jakarta: Kementerian Ristekdikti.

Kementerian Riset, Teknologi, dan Pendidikan Tinggi Republik Indonesia (Ministry of Research, Technology, and Higher Education) (MRTHE). 2017. Statistik Pendidikan Tinggi Tahun 2017 (Higher Education Statistical Year Book 2017). Jakarta: Pusdatin Iptek Dikti, Setjen, Kemenristekdikti.

Latifah, Emmy. 2016. "Precautionary Principle sebagai Landasan dalam Merumuskan Kebijakan Publik" [The precautionary principle as the basis in formulating public policies]. Yustisia Jurnal Hukum 5, No. 2 (May-August 2016): 275-297.

Lutchen, R. Kenneth. 2018. "Why Companies and Universities Should Forge Long-Term Collaborations." Harvard Business Review, 24 January 2018. https://hbr.org/2018/01/whycompanies-and-universities-should-forge-long-term-collaborations.

Mahkamah Konstitusi Republik Indonesia (Constitutional Court). 2018. Konsistensi pada Konstitusi dan Ideologi Negara: Laporan Tahunan Mahkamah Konstitusi RI 2017 [The consistency on the constitution and the ideology of the state: The 2017 annual report of the Constitutional Court of RI]. Jakarta: Kepaniteraan dan Sekretariat Jenderal Mahkamah Konstitusi Republik Indonesia.

Menteri Hukum dan Hak Asasi Manusia Republik Indonesia (Minister of Law and Human Rights) (Yasonna H. Laoly) (MLHR). 2017. "Perkembangan dan Tantangan Pengelolaan Regulasi di Indonesia" [The development and challenges of regulatory management in Indonesia] (Scientific oration at the opening of the $4^{\text {th }}$ National Conference on Constitutional Law, Jember, Indonesia, 10 November 2017).

Rekomendasi Jember (Jember Recommendations) tentang Penataan Regulasi di Indonesia [Jember Recommendations concerning the Arrangement of Regulations in Indonesia] (Jember Recommendations). 2017. (Jember, 12 November 2017).

Runnion, Timm, and Ivana Gibson. 2018. "Companies Can Address Talent Shortages by Partnering with Educators." Harvard Business Review, 4 June 2018, https://hbr.org/2018/0 6/companies-can-address-talent-shortages-by-partnering-with-educators. 
Sekretariat Kabinet Republik Indonesia (Cabinet Secretariat). 2015a. "Sambutan Presiden Joko Widodo [p]ada Ground Breaking Proyek-proyek [sic] Strategis Pemerintah Daerah Provinsi Kalimantan Timur, [d]i Kawasan Industri Buluminung, Kabupaten Penajam Paser Utara, 19 November 2015" [The greeting of President Joko Widodo at the ground breaking of strategic projects of Kalimantan Timur Local Government, in the Buluminung Industrial Estate, Penajam Paser Utara Regency, 19 November 2015]. Published 19 November 2015. http://setkab.go.id/sambutan-presiden-joko-widodo-pada-ground-breaki ng-proyek-proyek-strategis-pemerintah-daerah-provinsi-kalimantan-timur-di-kawasan-ind ustri-buluminung-kabupaten-penajam-paser-utara-19-november-2015/?yop_poll_tr_id=\&y op-poll-nonce-1_yp56673c37a09c4=65b6d74e25.

Sekretariat Kabinet Republik Indonesia (Cabinet Secretariat). 2015b. "Pengantar Presiden Joko Widodo [p]ada Sidang Kabinet Paripurna, [d]i Kantor Presiden, Jakarta, 2 November 2015" [The introduction of President Joko Widodo at the plenary meeting of the cabinet, at the Presidential Office, Jakarta, 2 November 2015]. Published 3 November 2015. http://setkab.go.id/pengantar-presiden-joko-widodo-pada-sidang-kabinet-paripurna-di-kant or-presiden-jakarta-2-november-2015/.

Sekretariat Kabinet Republik Indonesia (Cabinet Secretariat). 2016a. "Pidato Sambutan Presiden Joko Widodo pada Peluncuran Program Investasi Menciptakan Lapangan Kerja Tahap III dan Peresmian Pabrik PT Nesia Pan Pacific Clothing serta Peresmian Akademi Komunitas Industri Tekstil dan Produk Tekstil Surakarta, 22 Januari 2016" [The speech of President Joko Widodo at the launch of the Investment Programme to Create Employment Opportunities Phase III and the inauguration of PT Nesia Pan Pacific Clothing's factory as well as the inauguration of the Community Academy of Textile Industry and Surakarta's textile products, 22 January 2016]. Published 26 January 2016. http://setkab.go.id/pidatosambutan-presiden-joko-widodo-pada-peluncuran-program-investasi-menciptakan-lapang an-kerja-tahap-iii-dan-peresmian-pabrik-pt-nesia-pan-pacific-clothing-serta-peresmian-aka demi-komunitas-industr/.

Sekretariat Kabinet Republik Indonesia (Cabinet Secretariat). 2016b. "Pengantar Presiden Rapat Terbatas tentang Reformasi Hukum di Kantor Presiden, Selasa (11/10)" [The introduction of the president at the Limited Meeting concerning the Legal Reform at the Presidential Office, Tuesday (11/10)]. Published 11 October 2016. http://setkab.go.id/pen gantar-presiden-rapat-terbatas-tentang-reformasi-hukum-di-kantor-presiden-selasa-1110/.

Sekretariat Kabinet Republik Indonesia (Cabinet Secretariat). 2016c. "Arahan Presiden Joko Widodo [S]aat menerima [sic] Menerima Dewan Pengurus Pusat Asosiasi Kontraktor Listrik dan Mekanikal Indonesia (AKLI) \& Pengurus Pusat Asosiasi Profesionalis Elektrikal Indonesia (APEI) di Istana Negara, Rabu 15 Juni 2016" [The direction of President Joko Widodo when he [received] the Central Executive Council of the Association of Indonesian Electrical and Mechanical Contractors (AKLI) \& the Central Executive of the Association of Indonesian Electrical Professionals (APEI) at the State Palace, Wednesday 15 June 2016]. Published 15 June 2016. http://setkab.go.id/arahanpresiden-joko-widodo-saat-menerima-menerima-dewan-pengurus-pusat-asosiasi-kontrakto r-listrik-dan-mekanikal-indonesia-akli-pengurus-pusat-asosiasi-profesionalis-elektrikal-ind onesia-apei-d/.

Sekretariat Kabinet Republik Indonesia (Cabinet Secretariat). 2016d. "Pengantar Presiden Joko Widodo pada Rapat Terbatas mengenai Revisi Pengadaan Barang/Jasa Pemerintah, 
29 Desember 2016, di Kantor Presiden, Jakarta" [The introduction of President Joko Widodo at the limited meeting on the revision of the procurement of goods/services of the government, 29 December 2016, at the Presidential Office, Jakarta]. Published 29 December 2016. http://setkab.go.id/pengantar-presiden-joko-widodo-pada-rapat-terbatasmengenai-revisi-pengadaan-barangjasa-pemerintah-29-desember-2016-di-kantor-presidenjakarta/.

Sekretariat Kabinet Republik Indonesia (Cabinet Secretariat). 2017a. "Banyak Jadi Alat Pemerasan, Presiden Jokowi Akan Buat Lomba Pangkas Aturan" [Many became extortion tools, President Jokowi will create a competition to cut regulations]. Published 11 December 2017. http://setkab.go.id/banyak-jadi-alat-pemerasan-presiden-jokowi-akan-bua t-lomba-pangkas-aturan/.

Sekretariat Kabinet Republik Indonesia (Cabinet Secretariat). 2017b. "Pengantar Presiden Joko Widodo dalam Sidang Kabinet Paripurna, Selasa, 29 Agustus 2017 Pukul 14.00 WIB di Istana Merdeka" [The introduction of President Joko Widodo at the plenary meeting of the cabinet, Tuesday, 29 August 2017 at 14.00 WIB at Istana Merdeka]. Published 30 August 2017. http://setkab.go.id/pengantar-presiden-joko-widodo-dalam-sidang-kabinetparipurna-selasa-29-agustus-2017-pukul-14-00-wib-di-istana-merdeka/.

Sekretariat Kabinet Republik Indonesia (Cabinet Secretariat). 2017c "Pengantar Presiden Joko Widodo pada Sidang Kabinet Paripurna, di Istana Kepresidenan Bogor, 29 Mei 2017" [The introduction of President Joko Widodo at the plenary meeting of the cabinet at Istana Kepresidenan Bogor, 29 May 2017]. Published 29 May 2017. http://setkab.go.id/pe ngantar-presiden-joko-widodo-pada-sidang-kabinet-paripurna-di-istana-kepresidenan-bog or-29-mei-2017/.

Sekretariat Kabinet Republik Indonesia (Cabinet Secretariat). 2017d. "Pengantar Presiden Joko Widodo pada Rapat Terbatas mengenai Lanjutan Pembahasan Reformasi Hukum, 17 Januari 2017, di Kantor Presiden, Jakarta" [The introduction of President Joko Widodo at the Limited Meeting concerning the Continued Discussion on the Legal Reform, 17 January 2017, at the Presidential Office, Jakarta]. Published 17 January 2017. http://setkab .go.id/pengantar-presiden-joko-widodo-pada-rapat-terbatas-mengenai-lanjutan-pembahasa n-reformasi-hukum-17-januari-2017-di-kantor-presiden-jakarta/.

Sekretariat Kabinet Republik Indonesia (Cabinet Secretariat). 2017e. "Pengantar Presiden Joko Widodo [p]ada Sidang Kabinet Paripurna Senin, 24 Juli 2017 Pukul 10.00 WIB [d]i Istana Negara" [The introduction of President Joko Widodo at the plenary cabinet meeting Monday, 24 July 2017 at 10.00 WIB at the State Palace]. Published 24 July 2017. http://set kab.go.id/pengantar-presiden-joko-widodo-pada-sidang-kabinet-paripurna-senin-24-juli2017-pukul-10-00-wib-di-istana-negara/.

Sekretariat Kabinet Republik Indonesia (Cabinet Secretariat). 2018. "Pengantar Presiden Joko Widodo pada Sidang Kabinet Paripurna tentang Persiapan Peluncuran Online Single Submission (OSS), 16 Mei 2018, di Istana Negara, Jakarta" [The introduction of President Joko Widodo at the Plenary Cabinet Meeting concerning the Preparation of the Online Single Submission (OSS), 16 May 2018, at the State Palace, Jakarta]. Published 16 May 2018. http://setkab.go.id/pengantar-presiden-joko-widodo-pada-sidang-kabinet-paripurnatentang-persiapan-peluncuran-online-single-submission-oss-16-mei-2018-di-istana-negar a-jakarta/. 